\title{
Fred Jordan, o grande precursor da ousadia gráfica no Brasil
}

\author{
DARIO LUIS BORELLI
}

$\mathrm{F}$ RED JORDAN, designer gráfico alemão, naturalizado brasileiro, faleceu aos 73 anos de idade na manhã do último dia 26 de fevereiro, no Hospital Sírio Libanês. A seu pedido, o corpo foi cremado no cemitério Vila Alpina. Além de numerosos amigos e admiradores, deixou viúva a senhora Sônia Jordan e o filho de ambos, André Jordan.

Para ESTUDOS AVANÇADOS a perda de Fred Jordan é irreparável. Foi por suas mãos que a revista buscou pouco a pouco consolidar sua identidade visual, seja mediante o layout da capa ou a escolha cuidadosa dos tipos em que são compostos os textos selecionados para publicação.

ESTUDOS AVANÇADOS sente orgulho de ter recebido a colaboração desprendida e voluntária daquele que foi comparado por Olaf Leu - um dos designer mais conceituados da Europa - como o instrumentista que chegou a primeiro violino da orquestra. 
Nas páginas dedicadas à Criação ESTUDOS AVANÇADOS publicou, em sua edição número 19 (set./dez. 1993), um ensaio bilíngüe de fronteira entre a ciência e a arte de autoria de Fred Jordan, acompanhado de um encarte ilustrado sobre os experimentos prismáticos de Goethe. $\mathrm{O}$ encarte mostra como fazer experimentos com recursos simples, visando a facilitar o acesso aos estudos fundamentais de Goethe sobre a cor - a Farbenlehre.

Também, quando ESTUDOS AVANÇADOS cumpriu 10 anos de vida, homenageou Fred Jordan nas páginas dedicadas à Criação em seu número 31 (set./dez. 1997), reproduzindo alguns de seus admiráveis trabalhos gráficos, além de depoimentos de respeitados profissionais dentro de sua área de atuação.

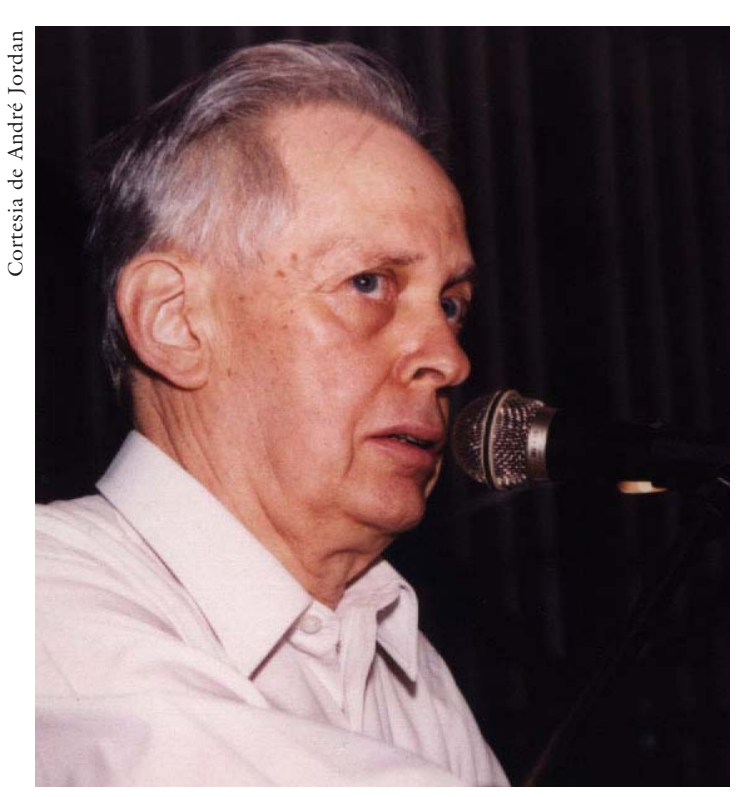

Fred Jordan (1927-2001)

$\mathrm{O}$ artista gráfico Tide Heilmeister, por exemplo, declarou a respeito de Fred Jordan: "Quem sou eu para dar um depoimento a respeito de um profisional cuja influência venho recebendo há quase 40 anos? Fred Jordan é, para mim, o grande precursor da ousadia gráfica no Brasil. Com sua batuta de maestro faz das artes gráficas uma beleza harmoniosa de formas que se fazem valer".

A artista plástica Maria Bonomi pronunciou-se sobre os disputados calendários que Fred Jordan e a gráfica paulista Niccolini produziam e distribuíam todos os anos a clientes e colecionadores: "Em 1952, quando a

gráfica Niccolini garantiu ao jovem Fred Jordan um espaço para enriquecer a visualidade do seu brinde padrão (a folhinha/calendário), com o intuito de proclamar sua excelência tecnológica, deflagrou uma revolução no mercado de publicação e da embalagem".

O designer Alexandre Wollner destacou a formação profissional de Fred Jordan. "Jordan, vindo da Alemanha, tem uma formação autodidata profunda aqui no Brasil, por força de sua intenção de evoluir. Hoje influencia o mercado gráfico com o uso da evolução de seus trabalhos artísticos e visuais, porém altamente tecnológicos, distanciando-se das influências de moda e persistindo em aprofundar-se nesse mistério que chamamos criatividade".

O geógrafo Aziz Ab'Sáber, com quem Fred Jordan manteve laços profundos de amizade, acompanhou de perto o desenvolvimento profissional do artista: "Ele 
dividia seu tempo entre a leitura de obras de grandes intelectuais e filósofos alemães, e projetos gráficos. Procurava assim um caminho para alcançar independência cultural e garantir a sua sobrevivência futura".

Fred Jordan nasceu em Berlim no ano de 1927. Veio com os pais para o Brasil em 1936, com nove anos de idade. Desde 1950 atuou como designer gráfico de empresas e a partir de 1980 tornou-se um profissional autônomo.

Durante toda a década de 60 foi diretor de arte e, nos anos 70, diretor técnico da Indústria Gráfica L. Niccolini. Projetou e produziu em 1958 a exposição $O s$ primeiros 30 mil anos para a Menninger Foundation, Kansas. Deu workshops no Cenafor, em São Paulo; na School of Design, Londres e na UCLA, Los Angeles. Fez, entre outras, as seguintes exposições individuais: Masp, 1978; Museu de Arte Moderna, Rio de Janeiro, 1984; Staatliches Museum für Angewandte Kunst, Munique, 1986. Possui, entre outros, trabalhos nas coleções do Museum of Modern Art, Nova Yorque e Die Neue Sammlung, Munique. Preparou números especiais dedicados ao design publicitário e gráfico no Brasil para as revistas Idea, Tokio, 1959, e Novum Gebrauchsgraphik, Munique, 1982. Tem trabalhos publicados em Graphis, Novum, Modern Publicity, Idea e História geral da arte no Brasil (coordenado por Walter Zanini), entre outros. Criou o layout da série, hoje interrompida, SBPC Documenta, e o logotipo da Abigraf (Associação Brasileira de Indústrias Gráficas).

A alegria de conviver e aprender com Fred Jordan não se encerra com a sua morte. O seu legado permanece vivo entre nós e nas páginas de nossa revista.

Dario Luis Borelli é editor assistente de ESTUDOS AVANÇADOS, mestre em Jornalismo e Editoração pela Escola de Comunicações e Artes da USP e professor de Produção Editorial da Universidade Anhembi Morumbi. 